\title{
TANTANGAN DAN PENGEMBANGAN PENDIDIKAN KRISTEN UNTUK ANAK USIA DINI
}

\author{
Areyne Christi \\ Wakil Ketua I Bidang Akademik Sekolah Tinggi Teologi Excelsius \\ areynechristi@sttexcelsius.ac.id
}

\begin{abstract}
Early childhood is the period beginning the most important and fundamental throughout the range of growth and development of human life. In early childhood, all children's potential is growing very fast. The facts found by the expert-ahlineurologi, stated that about $50 \%$ of the capacity of human intelligence has occurred when the age of 4 years and $80 \%$ had occurred when he was 8 years old. Growth functional nerve cells require a variety of educational situations that supports both the educational situation of families, communities and schools.
\end{abstract}

Keywords: Christian; Education; Children; Character

\begin{abstract}
Abstrak
Usia dini merupakan periode awal yang paling penting dan mendasar sepanjang rentang pertumbuhan dan perkembangan kehidupan manusia. Pada masa usia dini, semua potensi anak berkembang sangat cepat. Fakta yang ditemukan oleh ahli-ahlineurologi, menyatakan bahwa sekitar $50 \%$ kapasitas kecerdasan manusia telah terjadi ketika usia 4 tahun dan $80 \%$ telah terjadi ketika berusia 8 tahun. Pertumbuhan fungsional sel-sel syaraf tersebut membutuhkan berbagai situasi pendidikan yang mendukung, baik situasi pendidikan keluarga, masyarakat maupun sekolah.
\end{abstract}

Kata Kunci: Kristen; Pendidikan; Anak-anak; Karakter 


\section{PENDAHULUAN}

Dalam rangka memenuhi kebutuhan pendidikan anak usia dini, pemerintah sudah mengembangkan Kurikulum PAUD dan perangkatnya yang dijadikan acuan bagi penyelenggaraan PAUD. Kurikulum PAUD hendaknya disusun berdasarkan landasan teoritik, yuridis, dan empiris. Hingga saat inibelum ditetapkan Standar Nasional Pendidikan untuk PAUD sebagai acuan penyusunan KTSP. Untuk itu perlu disusun naskah akademik kajian kebijakan kurikulum PAUD. ${ }^{1}$

Di sisi lain prinsip otonomi daerah sesuai dengan Undang-undang No. 32 tahun 2004 tentang Pemerintahan Daerah menuntut pelaksanaan otonomi yang nyata dan bertanggungjawab dalam penyelenggaraan pendidikan sesuai dengan peraturan yang berlaku. Daerah berwenang untuk menangani urusan pendidikan yang dilaksanakan berdasarkan tugas, wewenang, dan kewajiban yang semestinya telah ada dan berpotensi untuk tumbuh, hidup dan berkembang sesuai dengan potensi dan kekhasan daerah. ${ }^{2}$ Selain itu daerah juga harus bertanggungjawab dalam penyelenggaraannya yang benar-benar sejalan dengan tujuan dan maksud pemberian otonomi, yang pada dasarnya untuk

\footnotetext{
${ }^{1}$ Depdiknas, Pengembangan Model Pembelajaran di Taman Kanak-Kanak (Jakarta:
}

memberdayakan daerah termasuk meningkatkan pelayanan dasar pendidikan yang merupakan bagian utama dari tujuan nasional.

Otonomi dalam bidang pendidikan yang diwujudkan dalam PP No. 25 tahun 2000 tentang Kewenangan Pemerintah dan Daerah Propinsi sebagai Daerah Otonom, pasal 2 ayat (2) dan (3) dalam bidang pendidikan telah dinyatakan bahwa pemerintah (Pusat) memiliki kewenangan antara lain (1) penetapan standar kompetensi siswa dan warga belajar serta pengaturan kurikulum nasional dan penilaian hasil belajar secara nasional serta pedoman pelaksanaannya, (2) penetapan standar materi pelajaran pokok, (3) penetapan pedoman pembiayaan penyelenggaraan pendidikan, dan (4) penetapan kalender pendidikan dan jumlah jam belajar efektif setiap tahun bagi pendidikan dasar, menengah dan luar sekolah.

Otonomi pengelolaan pendidikan ini diwujudkan dalam Undang-undang No. 20 Tahun 2003 tentang Sistem Pendidikan Nasional dan PP Nomor 19 Tahun 2005 tentang Standar Nasional Pendidikan. Halhal yang berhubungan dengan implementasinya dikembangkan dan dikelola oleh pelaksana di daerah terutama di daerah

Direktorat Pembinaan Taman Kanak-Kanak dan SD, 2005), 28

${ }^{2}$ Ibid. 
tingkat II dan sekolah. Dengan demikian daerah tingkat II dan sekolah memiliki kewenangan untuk merancang silabus dan pelaksanaannya disesuaikan dengan tuntutan kebutuhan peserta didik, keadaan sekolah, dan kondisi daerah berdasarkan pengalaman belajar, cara mengajar, dan menilai keberhasilan proses pembelajaran yang mengacu pada ketetapan pemerintah secara nasional sesuai dengan prinsip manajemen berbasis sekolah. $^{3}$

Menurut Undang-undang Nomor 20 Tahun 2003 tentang Sistem Pendidikan Nasional Pasal 1 angka 14 menyatakan bahwa Pendidikan Anak Usia Dini (PAUD) adalah suatu upaya pembinaan yang ditujukan kepada anak sejak lahir sampai dengan usia enam tahun yang dilakukan melalui pemberian rangsangan pendidikan untuk membantu pertumbuhan dan perkembangan jasmani dan rohani agar anak memiliki kesiapan dalam memasuki pendidikan lebih lanjut. $^{4}$

Secara rinci dalam undang-undang Sistem Pendidikan Nasional nomor: 20 tahun 2003 menerangkan: Pasal 1 Angka (1) menjelaskan tentang "Pendidikan adalah usaha sadar dan terencana untuk mewujudkan suasana belajar dan proses pembelajaran agar peserta didik secara aktif

\footnotetext{
${ }^{3}$ Depdiknas, Pengembangan Model Pembelajaran di Taman Kanak-Kanak (Jakarta : Direktorat Pembinaan Taman Kanak-Kanak dan SD, 2003), 8 .
}

mengembangkan potensi dirinya untuk memiliki kekuatan spiritual keagamaan, pengendalian diri, kepribadian, kecerdasan, akhlak mulia, serta keterampilan yang diperlukan dirinya,masyarakat, bangsa dan Negara", dan pasal 2 menjelaskan tentang "Pendidikan Nasional adalah pendidikan yang berdasarkan Pancasila dan UndangUndang Dasar Negara Republik Indonesia Tahun 1945 yang berakar pada nilai-nilai agama, kebudayaan nasional Indonesia dan tanggap terhadap tuntutan perubahan zaman" Dalam perkembangannya, masyarakat telah menunjukkan kepedulian terhadap masalah pendidikan, pengasuhan, dan perlindungan anak usia dini untuk usia 0 sampai dengan 6 tahun dengan berbagai jenis layanan sesuai dengan kondisi dan kemampuan yang ada, baik dalam jalur pendidikan formal maupun non formal. Berdasarkan aspek pedagogis, masa usia dini merupakan masa peletak dasar atau pondasi awal bagi pertumbuhan dan perkembangan selanjutnya. Artinya masa kanak-kanak yang bahagia merupakan dasar bagi keberhasilan dimasa datang dan sebaliknya.

\section{METODOLOGI PENELITIAN}

Artikel ini menggunakan metode penelitian pendekatan studi literatur.

${ }^{4}$ Departemen Pendidikan Nasional, Undangundang No. 20 Tahun 2003 tentang Sistem Pendidikan Nasional, (Jakarta: ,2003). 


\section{ANALISIS DAN HASIL PENELITIAN}

\section{Definisi Pendidikan Anak Usia Dini $\underline{\text { (PAUD) }}$}

Pendidikan Anak Usia Dini (PAUD) adalah jenjang pendidikan sebelum jenjang pendidikan dasar yang merupakan suatu upaya pembinaan yang ditujukan kepada anak sejak lahir sampai dengan usia enam tahun yang dilakukan melalui pemberian rangsangan pendidikan untuk membantu pertumbuhan dan perkembangan jasmani dan rohani agar anak memiliki kesiapan dalam memasuki pendidikan lebih lanjut. ${ }^{5}$

Secara umum tujuan pendidikan anak usia dini adalah mengembangkan berbagai potensi anak sejak dini sebagai persiapan untuk hidup dan dapat menyesuaikan diri dengan lingkungannya. Sedangkan Dr. Yuliani menulis: Proses pembelajaran pada anak usia dini hendaknya dilakukan dengan tujuan memberikan konsep-konsep dasar yang memiliki makna bagi anak melalui pengalaman nyata yang memungkinkan anak untuk menunjukkan aktivitas dan rasa ingin tahu secara optimal. ${ }^{6} \quad$ Moeslichatoen menulis: tujuan program kegiatan belajar anak TK adalah untuk membantu meletakkan dasar ke arah perkembangan sikap,

${ }^{5}$ Undang-undang Republik Indonesia No. 20 tahun 2003 tentang Sistem Pendidikan Nasional (Sisdiknas) (Bandung: Citra Umbara,2003), 4.

${ }^{6}$ Yuliani Nurani Sujiono, Konsep Dasar Pendidikan Anak Usia Dini (Jakarta: PT. Indeks, 2011), 2. pengetahuan, keterampilan, dan daya cipta yang diperlukan oleh anak didik dalam menyesuaikan diri dengan lingkungannya dan untuk pertumbuhan serta perkembangan selanjutnya. ${ }^{7}$ Anak usia dini adalah anak yang berada pada rentang usia $0-6$ tahun. Sedangkan TK adalah pada usia 4-6 tahun sehingga usia TK berada dalam rentang anak usia dini. Tujuan pendidikan anak usia dini menurut Ajeng Yusriana adalah untuk mencetak generasi yang tidak hanya memiliki pengetahuan mumpuni, tapi juga memiliki kepribadian yang baik. ${ }^{8}$

Dalam pengembangan pendidikan anak usia dini, diperlukan formasi terintegrasi antara peran guru sebagai pendidik, kurikulum, proses belajarmengajar serta evaluasinta. Salah satu hal penting yang harus dikembangkan adalah proses belajar mengajar dimana hal ini merupakan kunci utama dari dunia pendidikan terutama disekolah-sekolah, dimana proses belajar-mengajar adalah intinya dan pendidikan harusnya dilaksanakan disaat anak usia dini sebelum memasuki jenjang pendidikan sekolah dasar. Untuk meningkatkan mutu pendidikan yang menghasilkan Sumber Daya Manusia (SDM) berkualitas tidaklah mudah dibutuhkan suatu

\footnotetext{
${ }^{7}$ Moeslichatoen, Metode Pengajaran di Taman Kanak-Kanak (Jakarta: Rineka Cipta, 2004).

${ }^{8}$ Ajeng Yusriana, Kiat-kiat Menjadi Guru Paud (Jogyakarta: Diva Press, 2012), 7.
} 
proses yang cukup panjang dan melelahkan.

Sekolah merupakan suatu tempat untuk berlangsungnya proses belajar-mengajar (PBM) karena adanya interaksi antara guru dan murid, dimana, guru dan murid merupakan dua komponen terpenting.

\section{Pendidikan Kristen}

Pengertian dari pendidikan Kristen yang merupakan usaha sadar atau sengaja kepada anak didik supaya didalamnya mereka bertumbuh dan berkembang mencapai kedewasaan secara susila dan nilainilai kekeristenan atas dasar iman Kristen. Dalam hal ini mencakup tiga aspek yaitu; pengetahuan (kognitif), sikap dan nilai-nilai (afektif), dan keterampilan (psikomotor) yang berdasarkan iman Kristen. ${ }^{9}$ Oleh karena itu, untuk pendidikan anak usia dini, anak didik patut untuk menerima pengajaran yang mengandung nilai-nilai Alkitab pula.

Menanamkan nilai-nilai Alkitab sebagai dasar, kepada anak-anak merupakan suatu hal yang sangat penting. Amsal 22:6 berkata, "Didiklah orang muda menurut jalan yang patut baginya, maka pada masa tuanya pun ia tidak akan menyimpang dari pada jalan itu." Proses pendidikan ini menuntut harga yang sangat mahal yang harus dibayar khususnya oleh pihak orang

${ }^{9}$ Hardi Budiyana, Dasar-dasar Pendidikan Agama Kristen (Solo: Berita Hidup Seminary, 2011), 4. tua. Jika tidak, maka penyesalan akan terus dibawa hingga nafas terakhir.

Pengembangan nilai-nilai Alkitab kepada anak adalah terdapat dalam kitab Ulangan 6:6-9, Apa yang kuperintahkan kepadamu pada hari ini haruslah engkau perhatikan, haruslah engkau mengajarkannya berulang-ulang kepada anak-anakmu dan membicarakannya apabila engkau duduk di rumahmu, apabila engkau sedang dalam perjalanan, apabila engkau berbaring dan apabila engkau bangun. Haruslah juga engkau mengikatkannya sebagai tanda pada tanganmu dan haruslah itu menjadi lambang di dahimu, dan haruslah engkau menuliskannya pada tiang pintu rumahmu dan pada pintu gerbangmu. Hal ini harus diajarkan berulang-ulang kepada anak.

Mendidik anak menurut jalan yang patut baginya selalu merupakan tugas yang besar dan penting disetiap generasi karena semua yang terlibat dalam proses membesarkan anak, tapi apakah ada masa dimana tantangan lebih besar dari saat ini? Perkembangan anak dan cara pandang tentang hidup merupakan hasil dari proses mendidik. Disitulah anak akan mengembangkan pemikiran mereka tentang Tuhan, manusia, diri mereka (pentingnya 
diri, sumber keamanan, tujuan dalam hidup), dan tentang lingkungan dan cara pandang dunianya.

Tapi semakin jauh lingkungan keluar dari kebenaran Alkitab dan nilai, prioritas dan kepercayaannya, lebih sulit tugas kita mendidik anak. Ini sebagian disebabkan oleh pengaruh negative dan tekanan atas anak, tapi juga karena orangtua terlalu sering berpikir dan bertindak seperti lingkungan mereka. Mereka mengambil struktur kepercayaan dan hidup menurut nilai dan prioritas lingkungan itu. Dampaknya terhadap cara berpikir dan prilaku anak sangat besar dan dengan hanya melihat sekilas apa yang terjadi disekitar kita sudah menjelaskan semuanya. Apa yang dipercaya lingkungan akan selalu menentukan bagaimana itu hidup.

$$
\text { Menurut Padmonodewo }
$$

dalam kegiatan belajar anak harus dilakukan dengan cara menyenangkan seperti bernyanyi, bermain, mengucapkan syair, pengenalan menulis, dan berhitung sambil menggunakan media yang menarik atau sambil menggunakan gambar yang sesuai dengan minat anak. ${ }^{10}$ Disamping itu setiap anak perlu mendapatkan perhatian yang bersifat individual sesuai dengan kebutuhan anak usia prasekolah, dan kegiatan belajar di

10 Dwi Yulianti, Bermain Sambil Belajar Sains di Taman Kanak-Kanak (Jakarta: PT Indeks, 2010), 2.
Taman Kanak-Kanak adalah pembentukan perilaku melalui pembiasaan yang terwujud dalam kehidupan sehari-hari, dan bermain merupakan cara yang sesuai untuk mengembangkan kemampuan anak didik. ${ }^{11}$ Dalam mengembangkan kemampuan belajar anak berdasarkan nilai-nilai Alkitab sangat mendukung perkembangan kognitif, afektif, dan psikomotor mereka nantinya.

Untuk dapat mengembangkan nilainilai Alkitab berdasarkan kognitif, afektif, dan psikomotorik anak, perlu untuk diketahui lebih dahulu yang dimaksud anak disini adalah anak yang berusia $0-6$ tahun. Anakanak demikian diajar dalam pendidik anak usia dini (PAUD).

Menurut Mary Go Setiawani, dalam setiap tingkatan umur memiliki ciri khas masing-masing. Sebenarnya ciri khas setiap tingkatan umur yang akan disajikan bersifat umum. Karena setiap individu memang berbeda, kecepatan pertumbuhan antara pria dan wanita pun berbeda, ditambah lagi dengan pebedaan latar belakang keluarga dan lingkungan masyarakat, maka tidaklah heran bila ada perbedaan yang menonjol antara anak yang satu dengan yang lain. Hal-hal seperti inilah yang harus diperhatikan oleh seorang pendidik. Berikut disajikan ringkasan ciri khas tiap umur dan penerapan

\footnotetext{
${ }^{11}$ Ibid., 3.
} 
praktis yang harus diperhatikan oleh seorang pendidik. $^{12}$

Oswald Smith, menegaskan bahwa untuk sampai kepada Allah bukanlah melalui hal-hal berikut: ${ }^{13}$

"Bukan dengan Imam, bukan dengan
Paus atau Pendeta. Bukan dengan Nabi
atau pemuka agama manapun...Dan
bukan dengan Gereja dan agama Baptisan
atau Perjamuan Suci. Bukan dengan
perbuatan baik dan kehidupan yang
berakhlak tinggi. Bukan dengan seluruh
keadaan atau perbuatan Anda atau yang
dapat diperbuat oleh orang lain bagi anda;
melainkan dengan Kristus dan Kristus
saja."

Dalam pengertian tersebut diatas, para guru yang mengajar tidak mengabaikan pemberitaan Injil sehingga anak beroleh keselamatan. Dalam pembelajaran yang mereka terima dalam aspek kognitif tidak terlepas juga dari pemahaman akan keselamatan melalui Yesus Kristus, dengan cara penyampaian yang mudah dipahami anak usia dini. Oleh karena itu doronglah mereka untuk mengambil keputusan secara pribadi untuk percaya kepada Tuhan Yesus (Yoh. 1:12), sebelum melangkah kepembelajaran yang lain. Karena pemaparan tentang Injil adalah tujuan utama dalam pendidikan Kristen sebagaimana diperintahkan oleh Alkitab. ${ }^{14}$

${ }^{12}$ Ibid.

${ }^{13}$ Oswald Smith, Keajaiban Anugerah (Jakarta: Yayasan Pekabaran Injil Imanuel, 1977), 105.
Menurut

Yudowibowo

Poerwowidagdo, Pendidikan Kristen adalah untuk membantu peserta didik agar dapat mengembangkan iman dan pengetahuannya tentang Firman Tuhan Allah seperti yang termaktub dalam Alkitab Perjanjian Lama dan Perjanjian Baru, serta pengetahuan dan pengalamannya dalam kehidupan mereka sehari-hari di manapun berada. Dengan demikian mereka dapat meangaktualisasikan diri sesuai dengan maksud dan kehendak Tuhan Allah dalam penciptaan. Pendidikan Kristiani meliputi tiga hal yaitu Alkitab, Gereja dan Dunia. Alkitab yang dimaksudkan disini ialah Kitab Suci Perjanjian Lama maupun Perjanjian Baru secara utuh atau integral, dalam arti keduanya harus dilihat sebagai suatu kesatuan yang tidak dapat dipisahkan satu dengan yang lain. Gereja adalah persekutuan orang yang telah dipanggil dan yang percaya kepada Yesus Kristus sebagai Juru Selamat dunia, yang merupakan tubuh Kristus yang universal, yaitu persekutuan orang beriman kepada Yesus Kristus. Dunia dalam pengertian disini sebagai bahan yang pokok dalam pendidikan kristiani meliputi kehidupan manusia yang menyangkut ilmu pengetahuan, politik, ekonomi dan sebagainya. ${ }^{15}$

14 Robert E. Clark, Christian Education: Foundations for the Future (Chicago: Moody Press, t.th), 399.

${ }^{15}$ Yudowibowo Poerwowidagdo, Pendidikan Hak Asasi Manusia dalam Pendidikan Agama Kristen, 
Menjadi sebuah hal yang menarik adalah ketika muncul sebuah pertanyaan, seberapa pentingkah Perjanjian Lama dalam ruang lingkup Pendidikan Agama Kristen (PAK)? Mungkin pertanyaan ini kita anggap sambil lalu, atau tidak terlalu penting, atau memang kita belum mengetahuinya. Mungkin ada yang mengatakan bahwa Perjanjian Lama (PL) tidak terlalu penting karena PL sudah berlalu dan sudah digenapi oleh Perjanjian Baru (PB), atau PB telah menjelaskan tentang pendidika Kristen. ${ }^{16}$ Apabila kita mempelajari dengan baik, Yesus Kristus menggunakan PL dalam mengajar di pelayanan-Nya (Mat. 5:21-22; 22:39) Para murid Yesus juga menggunakan PL dalam pelayanan (pemberitaan Injil)? Ternyata PL menjadi hal penting dalam membangun konsep dan pelaksanaan PAK. Dengan kata lain, hal yang hendak dimaksudkan adalah PL digunakan dalam membangun dan membentuk PAK. Tentunya hal ini dilandasi bahwa PAK lahir setelah PL, walaupun dalam perspektif lain diungkapkan bahwa kekristenan sudah ada dalam PL. Michelle Anthony mengomentari pentingnya dasar Alkitab dalam pendidikan anak karena Allah

dalam Ajar Mereka Melakukan (Jakarta: BPK Gunung Mulia, 2003), 112-113.

${ }^{16}$ Rahman Assegaf, Pendidikan Tanpa Kekerasan: Tipologi Kondisi, Kasus, dan Konsep (Yogyakarta: Tirta Wacana Yogya, 2004) 87.

${ }^{17}$ Daniel Agung Kurniawan Budilaksono, Penerapan Pendidikan Kristen Perjanjian Lama dalam Era Modern, berkehendak menyediakan petunjuk tentang bagaimana memperhatikan serta memelihara anak. Baik Perjanjian Lama maupun Perjanjian Baru memberikan penjelasan mengenai perhatian terhadap kebutuhan fisik, emosi maupun kerohanian anak. ${ }^{17}$

Bangsa Yahudi adalah bangsa pertama yang memiliki sistem pendidikan Nasional pendidikan usia dini (Ul. 6:4-9) Pendidikan mereka tidak hanya secara teori, tetapi menjadi kegiatan sehari-hari dalam cara hidup dan keagamannya. ${ }^{18}$ Contoh Kitab Imamat yang mengajarkan semua tata cara hidup dan beragama. Pendidikan anak Yahudi bermula di rumah. Berpangkal dari peranan seorang ibu Yahudi. Tugas kewajiban ibu adalah untuk menjaga kelangsungan hidup rumah tangga yang juga terkait erat dengan tugas rohani mendidik anak-anaknya, khususnya ketika masih balita. ${ }^{19}$ Jauh- jauh hari sebelum anak berhubungan dengan dunia luar, anak terlebih dahulu mendapat pendidikan dari ibunya sehingga sesudah menginjak usia remaja/pemuda ia sudah mempunyai dasar yang benar. Contoh: Melalui cerita-cerita pepak.sabda.org/pustaka/050919/?kata=perjanjian+la ma.

${ }^{18}$ Robert R. Boehlke, Sejarah Perkembangan Pikiran dan Praktek Pendidikan Agama Kristen dari Plato sampai Ig. Loyola (Jakarta: BPK Gunung Mulia, 2005) 145.

19 Yulia Oeniyati, Silabus PAK Anak, http://www.sabda.org/pepak/pustaka/050836/. 
sejarah bangsa dan hari-hari peringatan/besar.

Perintah untuk memperhatikan pentingnya pendidikan anak diberikan Allah sendiri sejak zaman Abraham (Kej. 18:19), dilanjutkan pada zaman Musa (Kel.12:26-27) dan dipertegas kembali dalam Ulangan 4:9 ; $6: 1-9 ; 11: 18-21$ yang selanjutnya juga menjadi perhatian orang-orang bijak (Ams.1:8; 22:6; 29:17; Pkh. 12:1). Dengan demikian, sangatlah tepat jika Perjanjian Lama, dijadikan dasar untuk memahami pentingnya pendidikan anak. Salah satu bagian Perjanjian Lama yang perlu dijadikan dasar untuk memahami pentingnya pendidikan pengajaran anak adalah Ulangan 6:4-9. Menurut Ulangan 6: 7, bahwa pertamatama pendidikan Agama adalah tangung jawab orang tua. Kalimat dalam ayat 7 "haruslah engkau mengajarkannya berulangulang kepada anak-anakmu" dan dalam ayat 21 "maka haruslah engkau menjawab anakmu.." menunjukkan bahwa orang tua memiliki tugas dan tanggung jawab dalam pendidikan anak-anak mereka. Oleh karena perintah ini berkiatan dengan instruksi syema, maka orang tua pertama-tama bertanggung jawab atas pendidikan rohani anak-anak mereka. Ini merupakan tugas yang sangat mendasar dan penting untuk dilakukan orang tua kepada anak-anaknya. Orang tua

${ }^{20}$ Homrighausen, Pendidikan Agama Kristen (Jakarta BPK Gunung Mulia, 2004) 32. dianggap yang paling bertangung jawab dalam pendidikan anak-anak oleh karena mereka adalah orang yang terdekat.

Sebagaimana dikatakan oleh J. I. Packer bahwa Allah memakai manusia untuk mengajarkan Taurat kepada bangsa Israelseperti Musa, para imam dan para nabi. Murid-murid mereka adalah orang dewasa dari bangsa Israel, yang kemudian mereka bertanggung jawab untuk meneruskan kepada anak-anak mereka.Sebagian besar,pendidikan dilakukan oleh orang tua, tidak ada ruang kelas atau kurikulum yang tersusun. Melalui pembahasan ini, dapat disimpulkan bahwa Allah sangat mementingkan pendidikan anak dan peranan serta tanggung jawab orang tua dalam mendidik anak-anak mereka dengan benar. ${ }^{20}$ Pembinaan yang dimaksud dalam Kitab Perjanjian Lama (Ulangan 6 : 4-9) secara umum dilakukan secara informal, yaitu oleh keluarga-keluarga (orang tua). Penggunaan kurikulum anak usia dini alkitabiah yang berintegrasi dengan kurikulum pembungkus sekuler dapat dibenarkan, karena kurikulum anak usia dini alkitabiah tersebut tidak dijadikan sebagai kurikulum tersembunyi tetapi disampaikan secara terbuka dan jelas di dalam kelas agar murid-murid memahami pengetahuan sejati di dalam pembelajaran mereka. $^{21}$ Pada pengembangan sebuah

\footnotetext{
${ }^{21}$ Martin, Jane R,.(1976). What Should We Do with a Hidden Curriculum When We Find One?
} 
kurikulum Paud secara formal maka kurikulum terdiri dari tiga standar berdasarkan PERMENDIKNAS NO 58 dan di intgetrasi dalam alkitab sebagai berikut: Standar isi Ulangan 6:4-5, Standar proses pada Ulangan 4:6-9, Standar penilaian pada Ulangan 6:17-19.

Sebagai dasar pengembangan nilainilai Alkitab dalam kognitif, yaitu dengan mempunyai tujuan pembelajaran yang jelas yakni memberikan suatu perubahan yang nyata kepada kehidupan murid sesuai dengan keperluannya. Perubahan-perubahan kehidupan yang kita inginkan dalam kehidupan murid-murid adalah sebagai berikut: $^{22}$ (1) Lahir baru: Menerima Tuhan Yesus sebagai Juruselamat pribadi. (2) Pengetahuan dan pengertian: Siapakah Allah itu? Berapa besar kasih-Nya? (3) Bertumbuh dalam Tuhan: Mempersembahkan diri; Dipenuhi oleh Roh Kudus; beribadah; mengasihi orang lain; menerapkan firman Tuhan. (4) Sifat: sifat yang jahat harus dikalahkan dengan pertolongan Tuhan. Misalnya: mudah tersiggung, lekas marah, dan kemalasan. Mengatasi sifat suka berkelahi dengan minta pengampunan dan pertolongan Tuhan supaya dapat mengalahkan kelakuan jahat itu. (5)

Curriculum Inquiry, Vol. 6, No. 2. Retrieved May 15, 2011, from http://www.jstor.org/stable/1179759

22 Lelia Lewis, Mengajar Untuk Mengubah Kehidupan (Bandung: Kalam Hidup, 1994), 19-20.
Kepandaian: Dapat mencari ayat, bagian khusus dalam Alkitab, dan menghafal ayat.

\section{$\underline{\text { Peran Guru dalam Pendidikan Anak Usia }}$ Dini (PAUD)}

Dalam proses pendidikan agama Kristen kepada anak usia dini, diperlukan peran guru anak usia dini yaitu: ${ }^{23}$

Pertama, Peran guru dalam pembelajaran. Guru terbaik bagi anak usia dini melakukan dan mengembangkan pembelajaran yang berkelanjutan. Guru harus menyadari bahwa awal mula pengalaman pendidikan memberikan pondasi untuk menjadi guru yang peduli dan berkompeten. Guru yang melaksanakan refletif menggambarkan mengajar sebagai suatu perjalanan-perjalanan yang meningkatkan pengertian diri, sementara itu guru juga meningkatkan sen sensitivitas dan pengetahuan terbaik anak tentang bagaimana memfasilitasi belajar. Guru harus mengerti bahwa saat mereka mengajar mereka juga diajarkan; saat mereka membantu orang lain untuk berkembang, mereka juga membuat diri mereka sendiri berubah.

Kedua, Peran guru dalam berinteraksi. Guru anak usia dini akan sering berinteraksi dengan anak berbagai bentuk perhatian, baik interaksi lisan maupun

\footnotetext{
${ }^{23}$ Yuliani Nurani Sujiono, Konsep Dasar Pendidikan Anak Usia Dini, (Jakarta: INDEKS, 2013), 13.
} 
perbuatan. Guru harus berinisiatif memvariasikan interaksi lisan, seperti memberikan perintah, dan bercakap-cakap dengan anak. Atau yang bersifat interaksi nonverbal yang tetap seperti member senyuman, sentuhan, pelukan, memegang dengan mengadakan kontak mata, dan berlutut atau duduk setingkat dengan anak sehingga membawa kehangatan dan rasa hormat.

Ketiga, Peran guru dalam pengasuhan, pendidik anak usia dini menganjurkan untuk mengasuh dengan sentuhan dan kasih sayang. Pengasuhan saling mempengaruhi seperti pelukan, getaran, cara mengemong dan mengedong adalah untuk kebutuhan perkembangan fisik dan psikologis anak. Kontak fisik melalui bermain, memberikan perhatian, dan pengajaran adalah penting dalam mendorong perkembangan fisik, kesehatan emosionil dan kasih saying guru. Memelihara interaksi membantu anak mengembangkan gambaran diri positif dan konsep diri seperti pengalaman hormat mereka dan ikut sertanya kontak fisik dengan guru. Memberikan perhatian dengan penuh kasih saying dan menambah sentuhan keduannya yaitu perkembangan emosi dan kognitif.

Keempat, Peran guru dalam mengatur tekanan/stress. Guru membantu anak untuk belajar mengatur tekanan akan menciptakan permainan dan mempelajari lingkungan yang aman pengolahan tekanan dan dapat mengatasi kemampuan membantu perkembangan. Guru juga akan memberikan anak keterangan perkembangan yang tepat tentang peristiwa tekanan, memberikan penentraman hati lagi secara fisik, dan mendorong anak untuk menjawab pertanyaan, mengutarakan perasaan dan membicarakan pandangan mereka sendiri.

Kelima, Peran guru dalam memberikan fasilitasi. anak-anak membutuhkan kesempatan untuk bermain imajinatif, mengekspresikan diri, menemukan masalah, menyelidiki jalan alternative, dan menemukan penemuan baru untuk mempertinggi perkembangan kreatifitas. Untuk guru perluh memfasilitasi dengan memberikan berbagai kegiatan dan lingkungan belajar yang fleksibel serta berbagai sumber belajar. Kesempatan yang diberikan dapat mendorong timbulnya ekspresi diri anak. Guru dapat memberikan dorongan pada anak untuk memilih aktivitasnya sendiri, menemukan berbagai hal alternative, dan untuk menciptakan objek atau ide baru yang memudahkan perkembangan kemampuan berpikir berbeda, dan penanganan masalah yang orisinil.

Keenam, Peran guru dalam perencanaan. Para guru perlu merencanakan kebutuhan anak-anak untuk ativitas mereka, perhatian, stimulus dan kesuksesan melalui keseimbangan dan kesatupaduan di dalam 
kelas dan melalui implementasi design kegiatan yang terencana. Guru juga merencanakan kegiatan rutin beserta perlaihannya. Anak-anak harus dapat berpindah secara efektif dari satu area ke area lain yang lain secara aman, tidak terburuhburuh, di dalam kelompok maupun individual, sampai mereka telah siap. Guru dapat mempersiapkan aktivitas yang menciptakan suasana yang dapat menstimulasi anak dan membantu mereka memilih aktivitas atau mainan yang tepat. Guru juga harus fleksibel dan dalam menggunakan aktivitas alternative tergantung pada perubahan kondisi, perbedaan ketertarikan pada anak, dan situasi yang luar biasa.

Ketujuh, Peran guru dalam bimbingan dan pemeliharan. Bimbingan adalah proses bantuan yang diberikan oleh guru kepada anak didik dalam rangka memperhatikan kemungkinan adanya hambatan atau kesulitan yang dihadapi anak didik dalam rangka mencapai perkembangan optimal; sedangkan pemeliharaan adalah suatu kegiatan yang dilakukan dengan sadar untuk mempengaruhi pertumbuhan fisik dan perkembangan mental anak dengan cara tertentu untuk mencapai hasil tertentu. Dengan kata lain pemeliharaan adalah

${ }^{24}$ Andar Gultom dan Suriana Sitompul, Pembelajaran Pendidikan Agama Kristen Pada Anak Usia Dini, 45. melatih, menjaga, membantu, melindungi dan memantau.

\section{$\underline{\text { Kompetensi Dasar }}$}

Kompetensi dasar merupakan garis besar, bukan penjelasan detail. Kompetensi dasar merupakan kerangka, bukan harga mati. Jadi sewaktu-waktu dapat dikembangkan sesuai dengan tuntutan perubahan dan perkembangan yang terjadi di masyarakat. Kompetensi dasar dan hasil belajar yang telah dirumuskan dalam acuan menu pembelajaran pada anak usia dini akan di bahas lebih lanjut. ${ }^{24}$

\section{Moral dan Nilai-nilai Agama}

Pada aspek pengembangan moral dan nilai-nilai kristiani, kompetensi dan hasil yang ingin dicapai adalah kemampuan melakukan ibadah mengenal dan percaya akan ciptaan Tuhan, dan mencintai sesama.

Contoh kompetensi moral dan nilainilai agama adalah dengan mengajarkan anak berdoa. Pengertian mengenai cara berdoa dapat disampaikan kepada anak-anak ketika kita menyampaikan cerita Alkitab dimana ada orang yang berdoa. Disamping tujuan atau kebenaran yang ditentukan dalam pelajaran untuk hari itu ada baiknya memakai kesempatan juga untuk menambah ajaran mengenai cara berdoa sesuai dengan bahan 
cerita dalam Alkitab: Pertama, cerita tentang Nehemia ketika minta izin dari raja pergi ke Yerusalem untuk membangun kembali tembok kota itu, (Neh. 2:4-5), pakailah kesempatan untuk menekankan sikap yang tepat dalam doa: Nehemia sedang berbicara dengan raja dan melayaninya. Ia tidak dapat berlutut dan berdoa kepada Tuhan. Matanya harus terbuka dan tangannya sibuk dengan cawan minuman raja. Bahkan ia harus berbicara kepada raja sambil berdoa kepada Tuhan. Namun ia berdoa di dalam hati, dan Tuhan mengambulkan doa itu. Yang penting dalam doa ialah sikap hati kita. ${ }^{25}$

Dengan mengajarkan anak berdoa dan bertakwa kepada Tuhan bisa memenuhi standar kompetensi moral dan nilai-nilai agama.

\section{Fisik/Motorik}

Fisik adalah jasmani; badan; jasmaniah; badaniah. Fokus perkembangan fisik yaitu, kesadaran penuh pada tubuh, perkembangan motorik kasar, dan halus. Menurut Elizabeth yang dikutip oleh mansur bahwa perkembagan fisik sangat penting dipelajari karena secara langsung atau tidak langsung akan mempengaruhi prilaku anak sehari-hari. Secara langsung perkembangan fisik anak akan menentukan keterampilan anak dalam bergerak. Secara tidak langsung

${ }^{25}$ Leatha Humes dan Lieke Simanjuntak, Penuntun Guru Pak 1 \&2 (Jakarta: BPK Gunung Mulia, 1998), 93-94.

pertumbuhan dan perkembangan fisik akan mempengaruhi bagaimana anak itu memandang dirinya sendiri dan bagaimana dia memandang orang lain. Pada anak usia dini perkembangan fisik memerlukan keterampilan motorik sehingga otot syaraf yang mulai tumbuh dapat berfungsi dengan baik.

Perkembangan motorik anak usia dini mencangkup motorik kasar (gross motor skills) dan motorik halus (fine motor skills).

$$
\text { Perkembangan motorik kasar }
$$
diperlukan untuk keterampilan menggerakan dan menyeimbangkan tubuh, seperti: melompat, meloncat, dan berlari. Keterampilan motorik kasar menjadi lebih gesit dan serasi. Mereka bisa mengabungkan berlari dan berlompat dengan dua kaki, berjingkat dan melompat. Bergantung pada konteks sosial dan buadaya, beberpa anak usia lima tahun mulai menguasai keselarasan mata tangan yang diperlukan untuk mengyunkan raket untuk menghantam bola.

Perkembangan motorik halus meliputi perkembangan otot halus dan fungsinya. Otot ini berfungsi untuk melakukan gerakan-gerakan bagian tubuh yang lebih spesifik seperti menulis, melipat, merangkai, mengancing baju, menggunting, dan sebagainya. ${ }^{26}$

23.

\footnotetext{
${ }^{26}$ Andar Gultom dan Suriana Sitompul, 22-
} 
Anak-anak usia tiga, empat, dan lima tahun penuh tenaga dan tak henti-hentinya bergerak. Pada waktu bertumbuh, mereka mengemangkan dan memperhalus keterampilan gerak motori kasar dan halus. Anak-anak usia tiga tahun mengalami banyak npertumbuhan di bidang perkembangan fisik takala mereka mengupayakan keselarasan gerak tiap hari. Lari, lompat, dan panjat menjadi semakin otomatis dan bukan merupakan tindakan yang sadar atau bertujuan. Anak usia tiga tahun masih sedikit berlatih-latih dan sering jatuh dan bangun bangun lagi dan coba lagi. Gerak-gerak tubuh anak sering menjadi lebih serasi, bisa berlari mulus dan berhenti dengan mudah. ${ }^{27}$

Tujuan utamanya adalah agar anak dapat menguasai lingkungan melalui peningkatan dari kontrol tubuh dan pengembangan sikap, pengetahuan, ketrampilan dan prilaku-prilaku yang berhubungan dalam memelihara, menghormati, melindungi tubuh mereka. ${ }^{28}$

\section{Kognitif}

\section{Perkembangan}

kognitif mengambarkan bagaimana pikiran anak berkembang dan berfungsi sehingga dapat berpikir. Semua anak memiliki pola perkembangan kognitif yang sama yaitu

${ }^{27}$ Carol Seefeldt \& Barbara A. Wasik, Pendidikan Anak Usia Dini (Jakarta: Indeks, 2008) 65. melalui empat tahapan yaitu: Pertama, sensorik motorik (0-2 Tahun). Dalam perkembangan kognisi (kemampuan berpikir atau mental) selama stadium sensorik motorik, intelegensi anak baru nampak dalam bentuk aktivitas motorik sebagai reaksi stimuli sensorik. Dalam tahap ini yang penting adalah tindakan-tindakan konkret dan bukan tindakan yang imaginer. Kedua, preoperasional (2-7 tahun). Dimulai dengan penguasaan bahasa yang sistematis, permainan simbolis, imitasi serta bayangan dalam mental dan bersifat egosentrik. Ketiga, konkret operasional (7-11 tahun). Cara berpikir anak kurang egosentris, aspek dinamis dalam perubahan situasi sudah diperhatikan, analisis logis dalam situasi konkret. Keempat, formal operasional (11 tahun keatas). Berpikir operasional formal dan mempunyai dua sifat yang penting yaitu: deduktif hipotesis dan kombinatoris. ${ }^{29}$

\section{Bahasa}

Bahasa adalah kata/kalimat yang digunakan untuk menghubungkan bagian ujaran. Fokus perkembagannya yaitu, keterampilan mendengar, receptive language atau bahasa yang dapat dipahami, expressive language/bahasa yang diucapkan atau yang ditampilkan, menulis dan membaca. Tujuan utamanya adalah agar anak

\footnotetext{
${ }^{28}$ Retno Soendari \& Wismiarti, Sentra Persiapan (Jakarta: Pustaka Al-Falah, 2010) 12.

${ }^{29}$ Andar Gultom dan Suriana Sitompul, 23.
} 
menginterpretasikan secara akurat saat berkomunikasi dengan orang lain seakurat dia berkomunikasi dengan diri sendiri. ${ }^{30}$

Kebanyakan anak memiliki perkembangan bahasanya, dimulai dari menangis untuk mengekspresikan responsnya terhadap bermacam-macam stimulan. Setelah itu anak mulai memeram (cooing) yaitu menglafalkan bunyi yang tidak ada artinya secara berulang. Setelah itu anak mulai belajar kalimat dengan satu kata seperti "maem" yang artinya minta makan. Anak-anak terus membuat perolehan kosa kata baru dan pada usia 3-4 tahun mulai belajar menyusun kalimat tanya dan kalimat negatif. Pada aspek pengembangan kemampuan berbahasa, yang akan di capai adalah kemampuan mengunakan bahasa untuk pemahaman bahasa pasif dan dapt berkomunikasi secara efektif yang bermanfaat atau mengungkapkan pikiran dan belajar. Pada aspek pengembagan kemampuan berbahasa. Kompetensi dan hasil belajar yang ingin dicapai adalah kemampuan menggunakan bahasa untuk pemahaman bahasa pasif dan dapat berkomunikasi secara efektif yang bermanfaat untuk berpikir dan belajar. ${ }^{31}$

\footnotetext{
${ }^{30}$ Retno Soendari \& Wismiarti, Sentra Persiapan, 9.

${ }^{31}$ Andar Gultom dan Suriana Sitompul, 46.

${ }^{32}$ Carol Seefeldt \& Barbara A. Wasik, Pendidikan Anak Usia Dini, 73.
}

Bagi anak-anak usia tiga, empat dan lima tahun, tibalah masa pertumbuhan dasyat di bidang bahasa. Perbendaharaan kata meluas dan struktur semantik dan sintaksis bagahsa mereka menjadi semakin sulit. Perubahan dalam bahasa ini mewakili perkembangan kemampuan kognitif. Anakanak menjadi pemikir yang lebih rumit dan sejalan dengan pertumbuhan mereka, perubahan ini tercermin pada bahasa mereka. Anak-anak usia tiga, emapat dan lima tahun ingin tahu tentang bahasa dan semakin percaya kepada bahasa untuk memberitahukan keinginan dan kebutuhan mereka. $^{32}$

Sosial, Emosional, dan Kemandirian

Pada aspek pengembangan sosioemosional, kompetensi dan hasil belajar yang ingin dicapai adalah mengenal lingkungan alam, lingkungan sosial, ${ }^{33}$ peranan masyarakat dan menghargai kekristenan sosial dan budaya serta mampu mengembangkan potensi dan konsep diri, sikap terhadap belajar, kontrol diri, dan rasa memiliki. $^{34}$

Kepribadian seorang anak akan mudah dibentuk pada usia yang dini. Masa kanak-kanak memnag bersifat lentur, mudah

\footnotetext{
${ }^{33}$ Retno Soendari \& Wismiarti, Sentra Persiapan, 14.

${ }^{34}$ Andar Gultom dan Suriana Sitompul, 46.
} 
dibentuk. Lingkungan, masyarakat, kebudayaan, pendidikan dan sebagainya, dapat memberikan pengaruh secara langsung atau mengubah kepribadian dan tingkah laku seorang. Sebab itu adalah penting bagi seorang guru untuk sedini mungkin membentuk muridnya dengan kebenaran, supaya sejak kecil hidup Kristus sudah bertunas dan bertumbuh dalam hatinya. ${ }^{35}$

Dalam hal ini untuk dapat memenuhi standar kompetensi sosial, emosional dan mandiri, anak didik haruslah di ajarkan tentang hukum kasih yaitu: "Kasihilah Tuhan Allah mu dengan segenap hati mu dan kasihilah sesamamu seperti dirimu sendiri." Dengan demikian anak didik dapat menerapkan dalam kompetensi sosial, emosional dan mandiri.

\section{Seni \\ Perilaku yang mencerminkan} kreativitas alamiah pada anak usia dini dapat diidentifikasi dari beberapa ciri yang ada. Senang menjajaki lingkungan, mengamati dan memegang segala sesuatu, eksplorasi secara ekspansif dan eksesif. Rasa ingin tahunya besar, suka magajukan pertanyaan dengan tak henti-hentinya. Bersifat spontan manyatakan pikiran dan perasaannya. Suka berpetualang, selalu ingin mendapatkan pengalaman-pengalaman baru. Suka

${ }^{35}$ Mary Go Setiawan, Pembaharuan Mengajar (Bandung: Kalam Hidup, 2005) 14. melakukan eksperimen, membongkar, dan mencoba-coba berbagai hal, mempunyai daya imajinasi yang tinggi. Kemampuan pada aspek pengembangan seni dan kreativitas adalah kepekaan terhadap irama, nada, birama, berbagai bunyi, bertepuk tangan, serta menghargai hasil karya yang kreatif. ${ }^{36}$

\section{KESIMPULAN}

Pendidik atau guru pendidikan anak usia dini adalah suatu jembatan atau profesi yang memerlukan kompetensi, ketrampilan dan keahlian khusus dibidang keusiadinian. Ciri yang harus dimiliki seorang pendidik anak usia dini adalah Pertama, memiliki karisma atau wibawa dan dapat menjadi panutan atau teladan. Kedua, memiliki tanggung jawab secara sadar dalam mendidik, mengajar, dan membimbing anak. Ketiga, memiliki kemampuan merancang program pembelajaran serta mampu menata dan mengelola kelas secara professional.

\section{DAFTAR PUSTAKA}

$\underline{B u k u}$

Assegaf, Rahman. Pendidikan Tanpa Kekerasan: Tipologi Kondisi, Kasus, dan Konsep Yogyakarta: Tirta Wacana Yogya, 2004.

Boehlke, Robert R. Sejarah Perkembangan Pikiran dan Praktek Pendidikan Agama Kristen dari Plato sampai Ig.

\footnotetext{
${ }^{36}$ Andar Gultom dan Suriana Sitompul, 25
} 
Loyola, Jakarta: BPK Gunung Mulia, 2005.

Budiyana, Hardi. Dasar-dasar Pendidikan Agama Kristen Solo: Berita Hidup Seminary, 2011.

Departemen Pendidikan Nasional, Undangundang No. 20 Tahun 2003 tentang Sistem Pendidikan Nasional, Jakarta: , 2003.

Depdiknas, Pengembangan Model Pembelajaran di Taman KanakKanak, Jakarta: Direktorat Pembinaan Taman Kanak-Kanak dan SD, 2005.

Clark, Robert E. Christian Education: Foundations for the Future, Chicago: Moody Press, t.th.

Gultom, Andar. dan Suriana Sitompul. Pembelajaran Pendidikan Agama Kristen Pada Anak Usia Dini.

Homrighausen, Pendidikan Agama Kristen Jakarta BPK Gunung Mulia, 2004.

Humes, Leatha. dan Lieke Simanjuntak. Penuntun Guru Pak 1 \&2, Jakarta: BPK Gunung Mulia, 1998.

Lewis, Lelia. Mengajar Untuk Mengubah Kehidupan Bandung: Kalam Hidup, 1994.

Martin, Jane R (1976). What Should We Do with a Hidden Curriculum When We Find One? Curriculum Moeslichatoen, Metode Pengajaran di Taman Kanak-Kanak, Jakarta: Rineka Cipta, 2004.

Poerwowidagdo, Poerwowidagdo. Pendidikan Hak Asasi Manusia dalam Pendidikan Agama Kristen, dalam Ajar Mereka Melakukan, Jakarta: BPK Gunung Mulia, 2003.
Seefeldt, Carol. dan Barbara A. Wasik. Pendidikan Anak Usia Dini, Jakarta: Indeks, 2008.

Setiawan, Mary Go. Pembaharuan Mengajar, Bandung: Kalam Hidup, 2005.

Smith, Oswald. Keajaiban Anugerah, Jakarta: Yayasan Pekabaran Injil Imanuel, 1977.

Soendari, Retno. Dan Wismiarti, Sentra Persiapan, Jakarta: Pustaka Al-Falah, 2010.

Sujiono, Yuliani Nurani. Konsep Dasar Pendidikan Anak Usia Dini, Jakarta: PT. Indeks, 2011.

Undang-undang Republik Indonesia No. 20 tahun 2003 tentang Sistem Pendidikan Nasional (Sisdiknas) (Bandung: Citra Umbara, 2003.

Yulianti, Dwi. Bermain Sambil Belajar Sains di Taman Kanak-Kanak, Jakarta: PT Indeks, 2010.

Yusriana, Ajeng, Kiat-kiat Menjadi Guru Paud, Jogyakarta: Diva Press, 2012.

\section{$\underline{\text { Internet }}$}

Budilakosono, Daniel Agung Kurniawan. Penerapan Pendidikan Kristen Perjanjian Lama dalam Era Modern, http:// pepak.sabda.org/pustaka/050919/?ka ta=perjanjian+lama.

Oeniyati, Yulia. Silabus PAK Anak, http://www.sabda.org/pepak/pustaka/ 050836/.

$\underline{\text { Jurnal }}$

Inquiry, Vol. 6, No. 2. Retrieved May 15, 2011, from http://www.jstor.org/stable/1179759 
Excelsis Deo: Jurnal Teologi, Misiologi, dan Pendidikan 